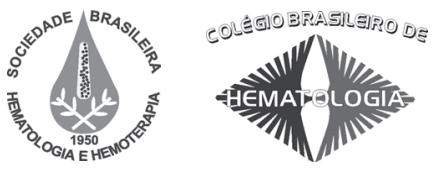

\title{
The role of thalidomide as maintenance after autologous stem cell transplantation in multiple myeloma
}

\author{
Papel da talidomida como manutenção após transplante autólogo de células-tronco hematopoéticas em \\ mieloma múltiplo
}

Angelo Maiolino

\begin{abstract}
Major progress was obtained over the last ten years in the treatment of multiple myeloma (MM). High dose chemotherapy with autologous stem cell transplantation (ASCT) and new drugs such as thalidomide, lenalidomide and bortezomib have completely changed the scenario of MM treatment. ASCT has become the mainstay of MM treatment for patients up to 65 years old. This strategy has been tested in randomized clinical trials which proved that ASCT can improve overall survival of MM patients. Unfortunately, the great majority of these patients will relapse in a few years after ASCT. Strategies of maintenance have been developed trying to improve the results of ASCT. Thalidomide has been tested in this setting in at least 4 randomized clinical trials with a significant impact on response rate, and event free and overall survival.l. Rev. Bras. Hematol. Hemoter. 2009;31(Supl. 2):30-31.
\end{abstract}

Key words: Multiple myeloma; thalidomide; autologous stem cell transplantation.

\section{Introduction}

Autologous stem cell transplantation (ASCT) has become the mainstay of the treatment of multiple myeloma $(\mathrm{MM})$ in patients up to 65 years old. ASCT has been shown to improve response rates and prolong progression free survival (PFS) and overall survival (OS) compared to conventional chemotherapy. Unfortunately, most patients relapse after ASCT suggesting that additional treatment is needed. Effective strategies for maintenance and/or consolidation have been developed trying to improve the results of ASCT. ${ }^{1,2}$

Thalidomide, an immunomodulatory agent with antiangiogenic properties, was first introduced in MM treatment by the Arkansas Group in 1999. ${ }^{3}$ The impressive results obtained in advanced relapse and refractory patients, with acceptable toxicity, led to this drug being considered as a potential candidate to be used as maintenance after ASCT.

At least, three randomized clinical trials were conducted testing the potential role of thalidomide with or without corticosteroids in MM patients after ASCT. The "Intergroup Francophone du Myeloma" conducted a trial (IFM 99-02) where "low risk patients" (with $\beta 2$-microglobulin $<3 \mathrm{mg} / \mathrm{dL}$ and/or absence of the chromosome 13 deletion as detected by FISH) were treated with 3 to 4 cycles of VAD (Vincristine, Adriamycin, Dexamethasone), followed by two consecutive ASCT conditioned with $140 \mathrm{mg} / \mathrm{m}^{2}$ and $200 \mathrm{mg} / \mathrm{m}^{2}$ melphalan, respectively. Two months after ASCT, patients were randomized to receive no maintenance (Arm A), pamidronate (Arm B) or pamidronate plus thalidomide at a dose of $400 \mathrm{mg}$ /day (Arm C). In terms of response rate, the IFM 99-02 showed that maintenance with thalidomide improves overall response rates (complete response - CR + very good partial response - VGPR) compared to the other strategies (67\% Arm C vs. $57 \%$ Arm B vs. $55 \%$ Arm A; $p=0.03)$. The 3 -year probability of event-free survival was superior in the thalidomide arm $(52 \%$ vs. $36 \%$ in Arm A vs. 37\% in Arm B; p < 0.009) and the 4-year probability of overall survival was also improved in the thalidomide arm ( $87 \%$ vs. $74 \%$ in Arm B vs. $77 \%$ in Arm A). Drug related adverse events, in particular grade 3 or 4 neuropathy, led to discontinuation of thalidomide in $39 \%$ of patients. ${ }^{4}$

The Tunisian Group designed a trial comparing a strategy of double ASCT (Arm A) versus single ASCT followed by maintenance therapy with $100 \mathrm{mg}$ /day thalidomide for six months (Arm B). A total of 195 patients

Professor adjunto de Hematologia - Universidade Federal do Rio de Janeiro (UFRJ) - Rio de Janeiro-RJ. 
were enrolled in this study (Arm A - $n=97$; Arm B - n =98). In both arms, patients received a first line therapy with thalidomide + dexamethasone. In an intention to treat analysis and a median follow-up of 33 months, authors observed better 3 -year OS and PFS for patients treated with ASCT plus thalidomide (OS: 65\% in Arm A and 85\% in Arm B; $p=0.04$; PFS: $57 \%$ in Arm A and $85 \%$ in Arm B; $p=0.02)^{5}{ }^{5}$

In another recently published study, the Australian Group reported the results of a clinical trial comparing maintenance with thalidomide + prednisone versus prednisone alone after a single ASCT. A total of 269 patients were enrolled in the study, 129 received prednisone alone and 114 received 12 months of thalidomide $(200 \mathrm{mg}$ /day) plus prednisone. After a median follow-up of three years, the authors observed an improvement in PFS and OS for the thalidomide group (PFS: $42 \%$ vs. $23 \%$; $p<0.01$ and OS: $86 \%$ vs. $75 \%$; $p=0.004) .6$

Maintenance with thalidomide after ASCT has also been prospectively studied by the "Brazilian Multiple Myeloma Study Group". From October 2003 to July 2008, 212 under 70year-old untreated patients were enrolled in a prospective randomized multicenter study. The treatment consisted of three phases: (1) induction with 3-5 cycles of VAD; (2) high-dose cyclophosphamide $(4 \mathrm{~g} / \mathrm{m} 2)$ plus G-CSF for stem cell mobilization; (3) melphalan $\left(200 \mathrm{mg} / \mathrm{m}^{2}\right)$ and ASCT. On day +60 post-ASCT, patients were randomized to receive dexamethasone ( $40 \mathrm{mg} / \mathrm{d} \times 4$ days every 28 days) with (Arm A) or without (Arm B) thalidomide (200 mg daily) for 12 months or until disease progression. The median age was 55 years (2770 ) and $52 \%$ were male. The median serum beta- 2 microglobulin was $3.66 \mathrm{mg} / \mathrm{dL}$, and $33 \%$ of patients were ISS stage 3,36\% were ISS stage 2 and $24 \%$ had deletion of chromosome 13 . In July of 2008, 93 patients (44\%) were randomized: 54 in Arm A and 39 in Arm B. The clinical characteristics of the groups were similar. The median follow-up from diagnosis was 15 months. PFS in Arms A and B were $42 \%$ (95\% confidence interval [CI]: $22-62)$ and $25 \%(95 \%$ CI: 5-45), respectively $(\mathrm{p}=0.07)$. A multivariate analysis that included baseline serum beta-2microglobulin and deletion of chromosome 13 showed that maintenance with thalidomide was significantly associated with better PFS (hazard ratio: $2.43 ; 95 \% \mathrm{CI} 1.10-5.35 ; \mathrm{p}=0.03$ ). Overall survival was $65 \%$ in Arm A $(95 \%$ CI $35-95)$ and $74 \%$ in Arm B (95\% CI $44-100), p={ }^{2}{ }^{7}{ }^{7}$

\section{Conclusion}

Data emerging from 4 randomized clinical trials, despite differences in strategies and in control arms, strongly suggest that thalidomide can improve response rate, event free survival and overall survival after ASCT for patients with MM. Probably the best maintenance strategy is to use lower doses of thalidomide (100 to $200 \mathrm{mg} /$ day) for a short period of time (6 to 12 months) to reduce toxicity and to avoid thalidomide resistance.

\section{Resumo}

Grandes progressos foram obtidos nos últimos anos no tratamento do mieloma múltiplo (MM). Quimioterapia em altas doses seguida de transplante autólogo de células-tronco hematopoéticas (TCTH) e a utilização de novas drogas, como a talidomida, lenalidomida e bortezomibe, mudaram completamente o cenário de tratamento do MM. O TCTH tornou-se padrão na abordagem de pacientes com MM recém-diagnosticado e idade inferior a 65 anos. Esta estratégia foi testada em estudos multicêntricos e randomizados, que demonstraram uma vantagem em termos de sobrevida global para os pacientes submetidos a TCTH. Infelizmente, a grande maioria dos pacientes irá recair em poucos anos após o TCTH. Estratégias de manutenção ou consolidação foram então desenvolvidas com o intuito de melhorar estes resultados. A talidomida foi testada como manutenção em pelo menos quatro estudos randomizados, tendo sido demonstrado um impacto favorável em termos de taxa de resposta e prolongamento da sobrevida global. Rev. Bras. Hematol. Hemoter. 2009;31(Supl. 2):30-31.

Palavras-chave: Mieloma múltiplo; talidomida; transplante autólogo de células-tronco hematopoéticas.

\section{References}

1. Attal M, Harousseau JL, Stoppa AM, Sotto JJ, Fuzibet JG, Rossi JF, et al. A prospective, randomized trial of autologous bone marrow transplantation and chemotherapy in multiple myeloma. Intergroupe Français du Myélome. N Engl J Med. 1996;335(2):91-7.

2. Child JA, Morgan GJ, Davies FE, Owen RG, Bell SE, Hawkins K, et al. High-dose chemotherapy with hematopoietic stem-cell rescue for multiple myeloma. N Engl J Med. 2003;348(19):1875-83.

3. Singhal S, Mehta J, Desikan R, Ayers D, Roberson P, Eddlemon P, et al. Antitumor activity of thalidomide in refractory multiple myeloma. N Engl J Med. 1999;341(21):1565-71.

4. Attal M, Harousseau JL, Leyvraz S, Doyen C, Hulin C, Benboubker L, et al. Maintenance therapy with thalidomide improves survival in patients with multiple myeloma. Blood. 2006;108(10):3289-94.

5. Abdelkefi A, Ladeb S, Torjman L, Othman TB, Lakhal A, Romdhane $\mathrm{NB}$, et al. Single autologous stem-cell transplantation followed by maintenance therapy with thalidomide is superior to double autologous transplantation in multiple myeloma: results of a multicenter randomized clinical trial. Blood. 2008; 111(4):1805-10.

6. Spencer A, Prince HM, Roberts AW, Prosser IW, Bradstock KF, Coyle L, et al. Consolidation therapy with low-dose thalidomide and prednisolone prolongs the survival of multiple myeloma patients undergoing a single autologous stem-cell transplantation procedure. J Clin Oncol. 2009;27(11):1788-93.

7. Maiolino A, Hungria V, Oliveira-Duarte G, Oliveira L, Mercante D, Miranda E, et al. Thalidomide + dexamethasone as maintenance after single autologous stem cell transplantation improves progression-free survival (PFS) in advanced multiple myeloma. a prospective brazilian randomized trial. Blood (ASH Annual Meeting Abstracts) 112[11], 3703. 2008. Abstract

O tema apresentado foi proposto pela Organização do $8^{\circ}$ Simpósio da Associação Ítalo-Brasileira de Hematologia, realizado durante o

XIII Congresso de Transplante de Medula Óssea.

Publicado após concordância do editor.

Conflito de interesse: sem conflito de interesse

Recebido: 18/06/2009; Aceito: 08/07/2009 